\title{
A Rice GRAS Gene Has an Impact on the Success of Arbuscular Mycorrhizal Colonization
}

\author{
Valentina Fiorilli1 ${ }^{*}$, Veronica Volpe ${ }^{1}$, Silvia Zanini' ${ }^{1}$, Marta Vallino², Simona Abbà ${ }^{2}$, \\ Paola Bonfante ${ }^{1^{*}}$ \\ ${ }^{1}$ Department of Life Sciences and Systems Biology, University of Turin, Turin, Italy \\ ${ }^{2}$ Institute for Sustainable Plant Protection-National Research Council, Turin, Italy \\ Email: ${ }^{*}$ valentina.fiorilli@unito.it, ${ }^{*}$ paola.bonfante@unito.it
}

Received 23 June 2015; accepted 4 August 2015; published 7 August 2015

Copyright (C) 2015 by authors and Scientific Research Publishing Inc.

This work is licensed under the Creative Commons Attribution International License (CC BY). http://creativecommons.org/licenses/by/4.0/

(c) (i) Open Access

\begin{abstract}
Arbuscular mycorrhiza (AM) is one of the most spread symbiosis established between $80 \%$ of land plants and soil fungi belonging to the Glomeromycota. Molecular determinants involved in the formation of arbuscular mycorrhizas are still poorly understood. It has been demonstrated that in both Legumes and rice plants, several GRAS transcription factors are directly involved in both mycorrhizal signaling and colonization, namely NSP1, NSP2, RAM1, DELLA, DELLA-interacting protein (DIP1) and RAD1. Here, we focused on a rice GRAS protein, named Arbuscular Mycorrhizal 18 (OSAM18), previously identified as specifically expressed in rice mycorrhizal roots, and considered as an AM-specific gene. Phylogenetic analysis revealed that OsAM18 had a peculiar amino acid sequence, which clustered with putative SCARECROW proteins, even though it formed a separate branch. Allelic osma18 mutant displayed a drastic reduction in mycorrhizal colonization intensity and in arbuscule abundance, as mirrored by OsPT11 expression level. Non-mycorrhizal osam 18 plants displayed a comparable plant development and root apparatus compared with the WT, while mycorrhizal osam18 mutants showed a reduction of plant biomass compared with mycorrhizal WT plants. The results suggest that OsAM18 is a rice protein, which is likely to have an impact not only on the colonization process and AM functionality, but also on the systemic effects of the AM symbiosis.
\end{abstract}

\section{Keywords}

Rice, Arbuscular Mycorrhizal Symbiosis, GRAS Proteins, Transcription Factors

\footnotetext{
*Corresponding authors.
}

How to cite this paper: Fiorilli, V., Volpe, V., Zanini, S., Vallino, M., Abbà, S. and Bonfante, P. (2015) A Rice GRAS Gene Has an Impact on the Success of Arbuscular Mycorrhizal Colonization. American Journal of Plant Sciences, 6, 1905-1915. 


\section{Introduction}

The arbuscular mycorrhizal (AM) symbiosis is established between fungi of the Glomeromycota phylum and more than $80 \%$ of land plant species, being therefore the most widespread terrestrial symbiosis [1]. The most characteristic feature of the symbiosis is a highly branched fungal structure called arbuscule, which is located inside root cortical cells [2]: here nutrient exchanges between the two partners occur. The AM fungus provides the plant with mineral nutrients, such as phosphate, nitrogen and sulphur [3]-[5], while, in return, it receives carbon compounds essential for the completion of its life cycle [6]. The massive reorganization described in AM colonized plants requires a unique transcriptional program [7] which induces changes associated with metabolic pathways controlling nutritional exchanges, cell wall modifications, secondary metabolism, signal transduction, and protein turn-over [8]-[14]. On the basis of a RNAseq analysis, Xue and colleagues showed that 45 genes encoding transcriptional factors (TFs) or transcriptional regulators were significantly up-regulated in Lotus japonicus mycorrhizal roots when compared with non-mycorrhizal roots [15]. These genes belong to the main TFs families and include GRAS, AP2/ERF, NO APICAL MERISTEM, ARABIDOPSIS TRANSCRIPTION ACTIVATION FACTOR, CUP-SHAPED COTYLEDON (NAC)-domain, MADS, MYB, C2H2 zinc finger, bZIP, ARF, WRKY DNA binding domain, NIN-like protein and LOB domain. These results indicate how mycorrhizal symbiosis also leads to deep change in transcription regulation. Some of these TFs have already been reported to be induced during the AM symbiosis [10] [16] [17] and in some cases have also been characterized [18]-[20].

GRAS proteins belong to a huge family which has been divided in several subfamilies. The name derives from three family members, GAI (GIBBERELLIC ACID INSENSITIVE), RGA (REPRESSOR of GAI) and SCR (SCARECROW) [21]. Plant GRAS TFs are involved in diverse biological processes, such as root and shoot development, regulation of phytohormone signalling pathway, abiotic stress [22]-[25] and nodule development [26], and they have been reported to play a role also in arbuscular association [18]. GRAS proteins are well characterized in legumes, where NODULATION SIGNALING PATHWAY 1 (NSP1) and NSP2 are considered essential for nodule development [26] [27] and involved in AM colonization process [28] [29], where they cause a decrease of root colonization. Other GRAS TFs, such as Required for Arbuscular Mycorrhization 1 (RAM1), Required for arbuscule development (RAD1) and DELLA protein, were recently identified in L. japonicus and Medicago truncatula. These genes have a functional role in arbuscule development [15] [18] [30]. The homologues of NSP1 and NSP2 have also been studied in rice, where at least 60 GRAS genes have been identified [31]. In detail, OsNSP1 and OsNSP2 are capable to fully restore the phenotype of the corresponding $L$. japonicus nsp 1 and $n s p 2$ mutants [21], suggesting a conservative role of these genes in both Legumes and monocots. Moreover, both genes have been identified as indispensable for strigolactone biosynthesis [32]. Rice lines mutated in SLR1/DELLA were shown to be unable to form AM symbiosis [33]. Other GRAS components have been identified as crucial for AM establishment in rice: among them, DELLA Interacting Protein 1 (DIP1), which interacts both with DELLA and OsRAM1 [33]. All these GRAS-domain proteins form a complex that has been proposed to be directly associated with mycorrhizal gene expression [33].

Here we focused our study on the biological function of a rice GRAS protein, named Arbuscular Mycorrhizal 18 (OsAM18), previously identified as exclusively induced in mycorrhizal roots during transcriptomic analysis [34] [35]. To assess whether this protein played a role during AM association, we took advantage of the availability of an osam 18 mutant rice line. A drastic reduction in mycorrhizal colonization intensity and in arbuscule abundance was observed in the root system of the osam 18 mutant. Despite this alteration, the arbuscule morphology displayed a normal phenotype. In addition, the mycorrhizal osam 18 mutants showed a decrease of fresh weight both in shoots and roots compared with mycorrhizal WT plants, whereas such a reduction of plant development was not observed in non-mycorrhizal mutants and WT plants. This result suggests that OsAM18 is likely to have an impact not only on the colonization process, but also on the systemic effects of the AM symbiosis.

\section{Materials and Methods}

\subsection{Biological Material and Growth Conditions}

Rice (cv Nipponbare) line carrying Tos17 insertion into osam 18 coding sequence (line NC5532) was selected from public databases (http://signal.salk.edu/cgi-bin/RiceGE) and provided by the Rice Genome Resource Center of the National Institute of Agrobiological Sciences (RGRC-NIAS), Japan. To isolate homozygous mutants, 
DNA extraction [36] and two rounds of PCR were carried out. Wild-type and mutated loci were distinguished by the use of specific primer pairs: combining an insertion-specific primer (Tos17:

ATTGTTAGGTTGCAAGTTAGTTAAGA) with a gene-specific primer allowed to identify the mutant allele (OsAM18f: ATTCCCTCAGCAACAACCAC), while two gene-specific primers spanning the insertion amplified the wild-type allele (OsAM18f: ATTCCCTCAGCAACAACCAC; OsAM18r:

TATGGTCGGAAGCCTGACTC). The primers were provided from public databases

(http://signal.salk.edu/cgi-bin/RiceGE). Only seeds of the identified homozygous plants were used for the subsequent experiments.

Seedlings of Oryza sativa ssp. japonica cv. Nipponbare wild-type and of osam 18 mutant line were inoculated with Funelliformis mosseae Gerd. \& Trappe BEG12 (MycAgro Lab, France, www.mycagrolab.com) by mixing the inoculum with sterile quartz sand $(30 \% \mathrm{v} / \mathrm{v})$ [11]. Plants were grown in a growth chamber under a $14 \mathrm{~h}$ light $\left(24^{\circ} \mathrm{C}\right) / 10 \mathrm{~h}$ dark $\left(20^{\circ} \mathrm{C}\right)$ regime, and watered once a week with tap water, and once a week with a modified Long-Ashton solution containing a low phosphorus concentration $\left(3.2 \mu \mathrm{M} \mathrm{Na}_{2} \mathrm{HPO}_{4} \cdot 12 \mathrm{H}_{2} \mathrm{O}\right)$ [37]. Plants were grown in 15-cm-high and 3-cm-diameter tube-pots and maintained in a growth chamber, as described above, until harvesting [28 days post-inoculation (dpi)].

Fresh weight of root and shoot tissues of the control (c) and mycorrhizal (myc), mutant and wild-type, rice plants was evaluated. Each tissue was isolated and the fresh weight was measured by means of analytical balance.

\subsection{In Silico Analyses}

OsAM18 nucleotide sequence was obtained from the Rice genome Annotation Project

(http://rice.plantbiology.msu.edu/), corresponding to the annotated "GRAS family transcription factor containing protein, expressed" (LOC_Os03g40080). The position of exons and introns was predicted using a program available at http://www.ncbi.nlm.nih.gov/IEB/Research/Ostell/Spidey/spideyweb.cgi.

The GRAS domain was identified by ScanProsite and NCBI Blastp tools [38]. Leucine-rich nuclear export signals (NESs) were predicted using NetNES server [39]. pSORT server was used to predict the protein localization.

All the rice sequences containing a GRAS domain were retrieved from the Rice Genome Annotation Project website (http://rice.plantbiology.msu.edu/index.shtml) [40]. Medicago truncatula and Lotus japonicus sequences containing a GRAS domain and belonging to the SCARECROW family were obtained from their respective databases.

On the basis of the HMM (Hidden Markov Model) logo of the GRAS family (PF03514) available at Pfam website (http://pfam.xfam.org/family/PF03514\#tabview=tab4), a custom Perl script was developed to find and isolate the most conserved part of the GRAS domain from each of the selected proteins. Only domains matching the following signature pattern $\mathrm{H}-[\mathrm{I}, \mathrm{V}]-[\mathrm{I}, \mathrm{V}]-\mathrm{D}(84,260)-\mathrm{W}(44,98)-\mathrm{W}-\mathrm{x}(10)-\mathrm{W}$ were used for the alignment and the subsequent phylogenetic analysis. Alignment was done by ClustalX v. 2.1 [41] and phylogenetic trees were generated by Neighbor-joining algorithm in R using "ape" v. 3.2 [42], "seqinr" v. 3.1-3 [43] and "ade4" v. 1.7-2 [44] packages.

\subsection{Morphometric Analysis}

In order to describe the root system architecture, the length of Crown Roots (CRs) and the number of Large Lateral Roots (LLRs) were annotated manually for each plant. The branching index $(\mathrm{BI}=\mathrm{n} \mathrm{LLR} / \mathrm{cm} \mathrm{CR})$ was calculated as described by Vallino and colleagues (2014) [45].

Portions of mycorrhizal roots were stained with cotton blue and the level of mycorrhizal formation was assessed according to Trouvelot and colleagues (1986) [46]. Over 80 root $\mathrm{cm}$ for six biological replicates were considered for each condition. Statistical tests were carried out through one-way analysis of variance (One-way Anova) and Tukey's post hoc test, using a probability level of $P<0.05$.

To assess the arbuscule phenotype, WT and osam 18 mutant roots were treated for $1 \mathrm{~h}$ in phosphate buffer, $\mathrm{pH} 7$, containing 3\% (w/v) paraformaldehyde. After washing in phosphate buffer, roots were embedded in $8 \%$ low melting agarose and sectioned with a series 1000 Microtome Sectioning System (Vibratome, St. Louis, MO, USA). Two hundred $\mu \mathrm{m}$ thick-vibratome sections were treated for $5 \mathrm{~min}$ in $0.5 \%$ commercial bleach, diluted in phosphate buffer, washed again, and then incubated for $2 \mathrm{~h}$ with wheat germ agglutinin-fluorescein isothiocyanate (WGA-TRITC) (Sigma-Aldrich, Milan, Italy), at a final concentration of $10 \mu \mathrm{g} / \mathrm{mL}$, to detect fungal cell 
walls. Working conditions for the Leica TCS SP2 confocal microscope (Leica Microsystems GmbH, Wetzlar, Germany) and for observations and image acquisition were used as described by Volpe and colleagues (2013) [20].

To examine the presence of aerenchyma, 25 different portions of the sampled LLRs were embedded and sectioned as described above. Cross sections, $100 \mu \mathrm{m}$ thick, were observed under a light microscope [Primo Star Zeiss (Carl Zeiss MicroImaging, Göttingen, Germany) with a Leica DFC425 digital camera (Leica Microsystems, Wetzlar, Germany) attached].

\subsection{Nucleic Acid Extraction and cDNA Synthesis}

Genomic DNA was extracted from $F$. mosseae sporocarps. Approximately 50 sporocarps were added to $50 \mu 1$ of 10X Red Taq (Sigma) buffer and crushed with a sterile pestle. The sample was heated at $95^{\circ} \mathrm{C}$ for $15 \mathrm{~min}$ and centrifuged at $12,000 \mathrm{~g}$ for $5 \mathrm{~min}$. The supernatant was transferred to a new tube and stored at $-20^{\circ} \mathrm{C}$. Fungal genomic DNA was used to test each primer pair used for real-time PCR to exclude cross hybridization.

Total RNA was extracted from rice roots of mycorrhizal and non-mycorrhizal plant grown via the sandwich method using the Plant RNeasy Kit (Qiagen), according to the manufacturer's instructions. Samples were treated with TURBO ${ }^{\text {TM }}$ DNase (Ambion, Austin, TX, USA) according to the manufacturer's instructions. The RNA samples were routinely checked for DNA contamination by means of RT-PCR (OneStepRT-PCR, Qiagen) analysis, using OsRubQ1 [34].

For single-strand cDNA synthesis, about $700 \mathrm{ng}$ of total RNA was denatured at $65^{\circ} \mathrm{C}$ for $5 \mathrm{~min}$ and then reverse-transcribed at $25^{\circ} \mathrm{C}$ for $10 \mathrm{~min}, 42^{\circ} \mathrm{C}$ for $50 \mathrm{~min}$ and $70^{\circ} \mathrm{C}$ for $15 \mathrm{~min}$. The final volume was $20 \mu \mathrm{l}$ and contained $10 \mu \mathrm{M}$ random primers, $0.5 \mathrm{mM}$ dNTPs, $4 \mu 15 \times$ buffer, $2 \mu 10.1 \mathrm{M}$ DTT, and $1 \mu 1$ Super-Script II (Invitrogen, Carlsbad, CA, USA).

\subsection{Real-Time Quantitative RT-PCR}

Quantitative RT-PCR (qRT-PCR) was performed using an iCycler apparatus (Bio-Rad, Hercules, CA, USA). Each PCR reaction was carried out in a total volume of $20 \mu$ l containing $1 \mu 1$ diluted cDNA (about $20 \mathrm{ng}$ ), $10 \mu \mathrm{l}$ $2 X$ SYBR Green Reaction Mix and $3 \mu 1$ of each primer $(3 \mu \mathrm{M})$. The following PCR program was used: $95^{\circ} \mathrm{C}$ for $90 \mathrm{~s}, 50$ cycles of $95^{\circ} \mathrm{C}$ for $15 \mathrm{~s}, 60^{\circ} \mathrm{C}$ for $30 \mathrm{~s}$. A melting curve $\left(80\right.$ steps with a heating rate of $0.5^{\circ} \mathrm{C}$ per $10 \mathrm{~s}$ and a continuous fluorescence measurement) was recorded at the end of each run to exclude the generation of non-specific PCR products [47]. All reactions were performed on at least three biological and three technical replicates.

Baseline range and $\mathrm{Ct}$ values were automatically calculated using iCycler software. Transcript levels were normalized to the Ct value of OsRubQ1 (OsRubQ1f: GGGTTCACAAGTCTGCCTATTTG; OsRubQ1r: ACGGGACACGACCAAGGA) [34] (OsPT11f: GAGAAGTTCCCTGCTTCAAGCA; OsPT11r:

GAGAAGTTCCCTGCTTCAAGCA) [34]. Only Ct values leading to a $\mathrm{Ct}$ mean with a standard deviation below 0.5 were considered [48]. Statistical tests were carried out through one-way Anova and Tukey's post hoc test, using a probability level of $P<0.05$. All statistical elaborations were performed using PAST statistical package (version 2.16) [49].

\section{Results and Discussion}

GRAS proteins belong to a family of transcriptional regulators unique to plants. They play important regulatory roles in a number of plant processes including signaling, development, abiotic stress, and symbiosis [22] [27]. Recent works demonstrated a direct involvement of several GRAS transcription factors in both mycorrhizal signaling and colonization, namely NSP1, NSP2, RAM1, DELLA, DELLA-interacting protein (DIP1) and RAD1 [15] [18] [29] [30] [32] [33] [50].

Here, we focused on a rice GRAS protein previously identified by a whole transcriptome analysis as being specifically expressed in rice mycorrhizal roots and silent in response to mock treatment [34]. No further functional characterization of this GRAS protein, named OsAM18, is available so far.

\subsection{Gene Isolation and Phylogenetic Analysis of OSAM18}

The OSAM18 cDNA sequence is $2334 \mathrm{nt}$ long. The corresponding genomic sequence spans a region around 
$4653 \mathrm{bp}$ on chromosome 3, and comprises six introns (Figure 1(a)). The predicted protein sequence is 777 amino acids long, with predicted molecular mass and $\mathrm{pI}$ of $88.3 \mathrm{kDa}$ and 5.53 respectively. GRAS proteins have highly variable $\mathrm{N}$-termini that differ in length and sequence, but share significant homologies throughout their C-termini. A putative GRAS domain was identified in OsAM18 using NCBI database and ScanProsite software. Both programs identify the GRAS domain between amino acids 334 and 680 (Figure 1(b)). No predicted nuclear localization signal (NLS) was identified in the amino acid sequence while a pSORT prediction indicated a potential cytoplasmic localization. Therefore, we hypothesize it could play a regulatory role at cytoplasmic level probably through protein-protein interaction. Moreover, like NSP2 and RAD1, OsAM18 has no predicted DNAbinding domains [15].

When aligned to GRAS domains of other rice proteins, OsAM18 clustered with putative SCARECROW proteins, remaining, however, as a separate branch (Figure 2(a)). A similar topology also arose when the analysis was done considering only SCARECROW proteins from rice, L. japonicus and M. truncatula: OsAM18 was part of a well-supported cluster, but formed a separate branch (Figure 2(b)).

The last 20 amino acids of OsAM18 were, in fact, poorly aligned to the other GRAS domains of the SCARECROW cluster, although the terminal part of the GRAS signature pattern $\mathrm{W}-\mathrm{x}(10)-\mathrm{W}$ was conserved (Figure 3).

It seems that OsAM18 has a peculiar sequence, which differentiates it from the other SCARECROW proteins.

\subsection{Analysis of osam18 Mutant Plants}

Since the structure of the GRAS proteins does not reveal much about the biochemical function [25], mutant analysis was used to shed light on its physiological and regulatory function. To understand the role of OsAM18 protein in rice plants and AM symbiosis, we took advantage of the osam 18 mutant generated by the endogenous retrotransposon Tos 17 insertion into the corresponding single copy gene LOC_Os03g40080 (Figure 1).

osam 18 mutants showed a normal plant development, with shoot and root morphologies comparable to those of the WT plants (Figure 4(a)). No significant differences was recorded between osam 18 mutants and WT in the fresh weight of both apparati (Figure 4(b)) and in the branching index (BI = nLLR/cmCR-Figure 4(c)), which describes the degree of the root apparatus branching [45] [51]. Rice is derived from a semi-aquatic ancestor, therefore its roots may form aerenchyma tissues. Observations by light microscope revealed no differences in the formation of aerenchyma tissues in the LLRs of WT and osam 18 mutants (Figure 4(d)).

\section{3. osam18 Mutants Display Impaired Mycorrhization}

To better investigate the role of OsAM18 during the presence of the AM fungus, we colonized WT and osam 18 mutant plants with Funelliformis mosseae. Mycorrhizal osam18 mutant plants showed a significant reduced

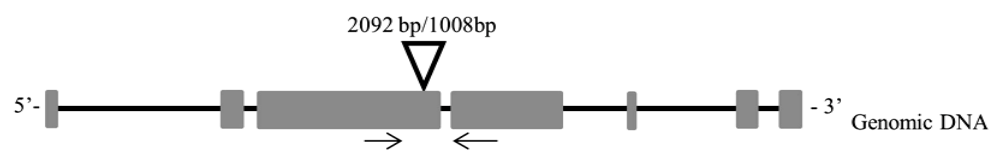

(a)

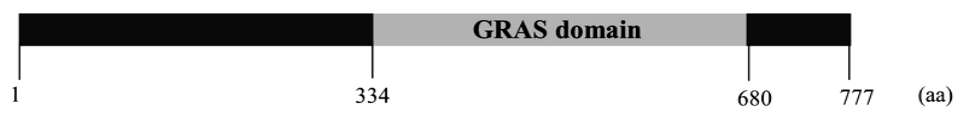

(b)

Figure 1. Features of genomic and protein sequence of OsAM18. (a) OsAM18 genomic DNA is composed of 7 exons and 6 introns (grey boxes and black bars, respectively). Arrows indicate the position of primers used for the mutant screening. Insertion site of Tos 17 in the NC5532 mutant line is indicated by a triangle. The insertion is in the third exon (in position $+2092 \mathrm{bp}$ from start codon if considering genomic sequence, or +1008 if considering cds), at the beginning of the GRAS domain; (b) OsAM18 protein sequence is 777 amino acids (aa) long with the putative GRAS domain positioned between the amino acids 334 and 680 of the protein. 


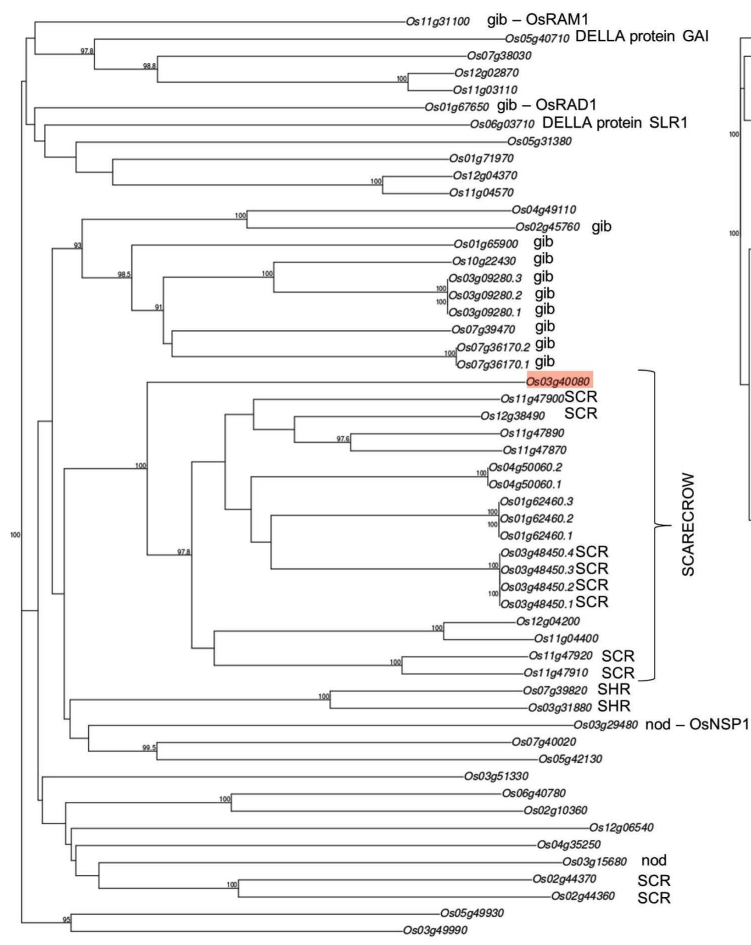

(a)

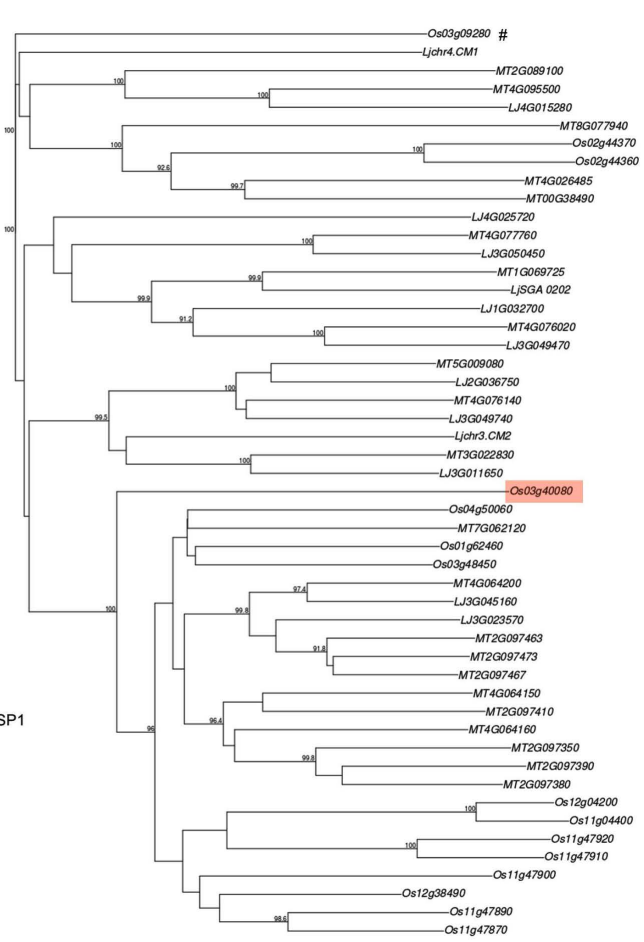

(b)

Figure 2. Phylogenetic analysis of OsAM18. (a) Unrooted phylogenetic tree of the rice (Oryza sativa) GRAS proteins. Os03g40080* (highlighted in red) is OsAM18. gib: gibberellin-responsive protein; SCR: SCARECROW protein; SHR: short root protein; nod: nodulation signaling pathway protein; (b) Rooted phylogenetic tree of putative SCARECROW GRAS proteins of Oryza sativa (Os), Lotus japonicus ( $\mathrm{Lj}$ ) and Medicago truncatula (Mt). Os03g40080 (highlighted in red) is OsAM18. \# indicate the outgroup.

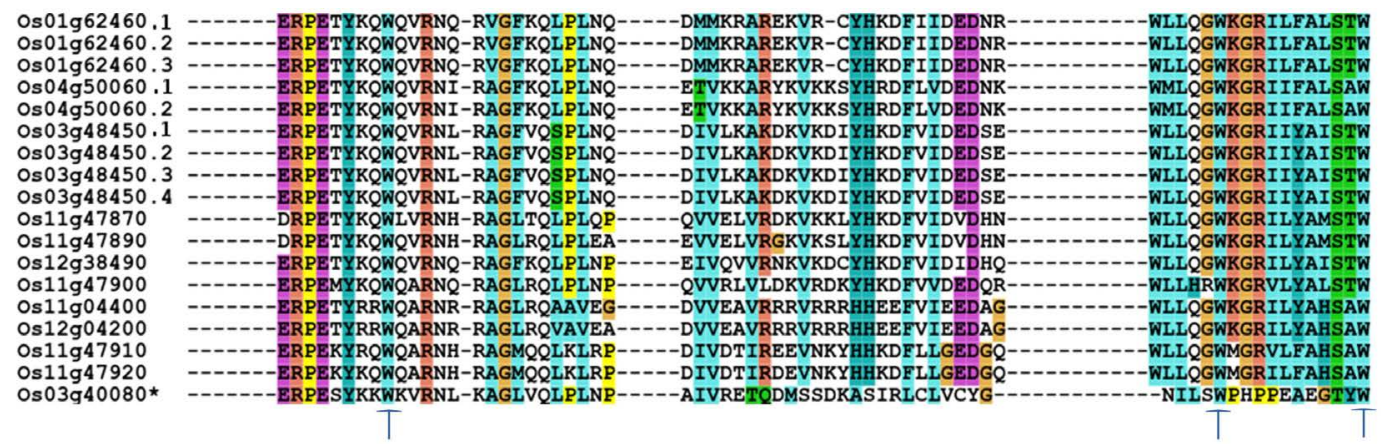

Figure 3. Alignment of GRAS domains belonging to the SCARECROW cluster. The figure shows an excerpt from the alignment of all the GRAS domains represented in the unrooted NJ tree. In particular, proteins belonging to the SCARECROW cluster are represented in the final region of the alignment, in which it is possible to recognize the terminal part of the GRAS signature pattern $\mathrm{W}(44,98)-\mathrm{W}-\mathrm{x}(10)-\mathrm{W}$ (indicated with arrows). Os03g40080 (indicated with an asterisk) is OsAM18.

shoot and root fresh weight compared to mycorrhizal WT plants (Figure 5(a)), indicating a negative impact on plant development. The colonized roots were assessed at $28 \mathrm{dpi}$ accordingly to Trouvelot and colleagues (1986) [46]: osam 18 mutant roots showed a statistically significant reduction (about 50\%) of percentage of mycorrhizal intensity $(\mathrm{M} \%)$ and arbuscules abundance $(\mathrm{A} \%)$ in the root system compared to the WT (Figure 5(b)). The lower abundance of arbuscules was confirmed by the measurements of OSPT11 expression level, since this plant phosphate transporter is considered a molecular marker for arbusculated cells. As shown in Figure 5(c), osam18 mutants showed a statistically significant lower OsPT11 mRNA abundance compared to the WT (about 


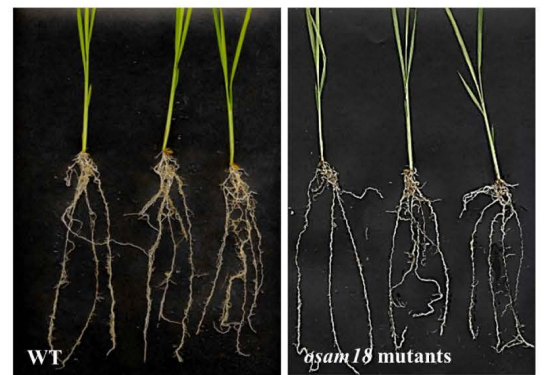

(a)

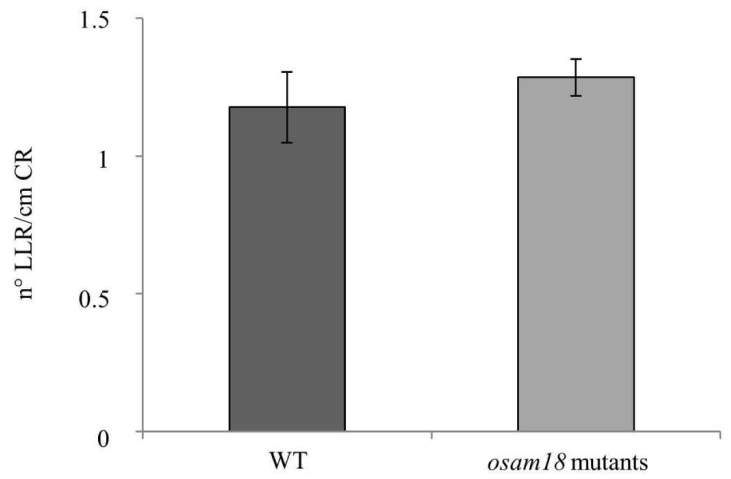

(c)

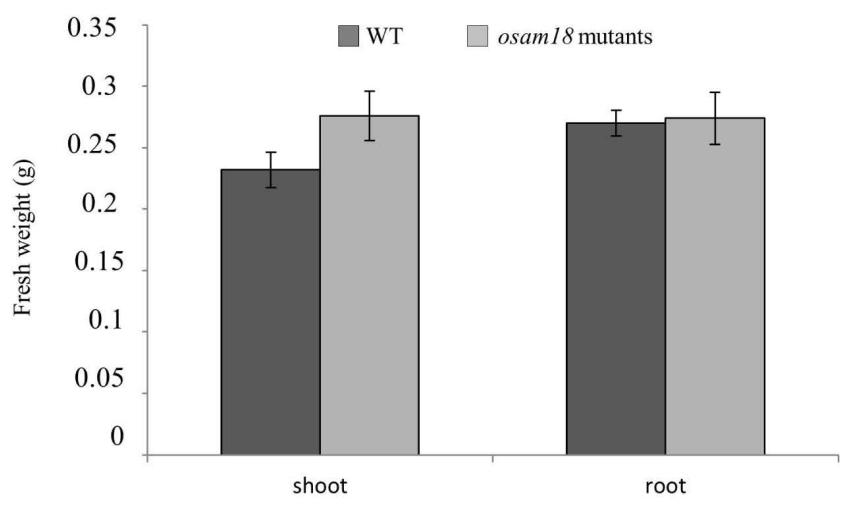

(b)

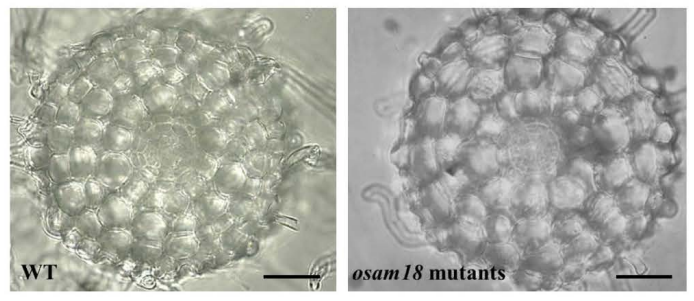

(d)

Figure 4. Phenotyping of osam 18 mutants. (a) WT and osam 18 mutant plants showed a similar macroscopical phenotype, with a normal shoot and root development in three independent biological replications; (b) fresh weight of shoot and root of osam 18 mutants and WT plants. Data are the average of six plants and \pm SE are represented by bars; (c) osam 18 mutants and WT plants showed no significant difference in the branching index $(\mathrm{BI}=\mathrm{nLLR} / \mathrm{cmCR})$. Data are the average of five biological replications and \pm SE are represented by bars; (d) LLRs cross section of WT and osam 18 mutant plants: no aerenchyma tissue is evident. Scale bars: $33 \mu \mathrm{m}$.

$50 \%$ ) corroborating the reduction of AM colonization level. To investigate whether OsAM18 knock-out also affected arbuscule morphology, WT and osam 18 mutant roots were stained with WGA-TRITC which detects the fungal cell wall and reveals the arbuscule morphology. Differently to the severe mycorrhizal phenotype detected in other mutated AM-marker GRAS genes, the osam 18 mutant fungal structures had the same morphology observed in WT. Indeed, osam18 mutant displayed fully developed and highly branched arbuscules (Figure 5(d)).

\section{Conclusions}

Taken together, these results demonstrated that the knock-out of OSAM18 gene led to a significantly reduced degree of mycorrhization but had no effect on the arbuscule morphology.

As a first hypothesis, the reduced colonization level could be related to the peculiar root system of rice, where a different susceptibility to AM fungi had been demonstrated [45] [51]. However, in the osam 18 mutants, the density of LLR, considered as the preferential niche for AM fungi [45] [51], was similar to the WT plants. Therefore, the reduced colonization level detected in osam 18 mutant does not seem to be a consequence of a reduced root branching. AM colonization in rice also depends on specific tissues. It has in fact been demonstrated that the aerenchyma increase is negatively correlated with AM colonization [45]. However, no change in aerenchyma production was detected in osam 18 mutant LLR. Lastly, since the arbuscule morphology proved to be normal, we hypothesized that the perifungal membrane was regularly assembled around the thin arbuscular branches [4] [52] leading to a correct expression of OsPT11. We found indeed a lower OsPT11 mRNA level, which probably mirrored the lower arbuscule number. 


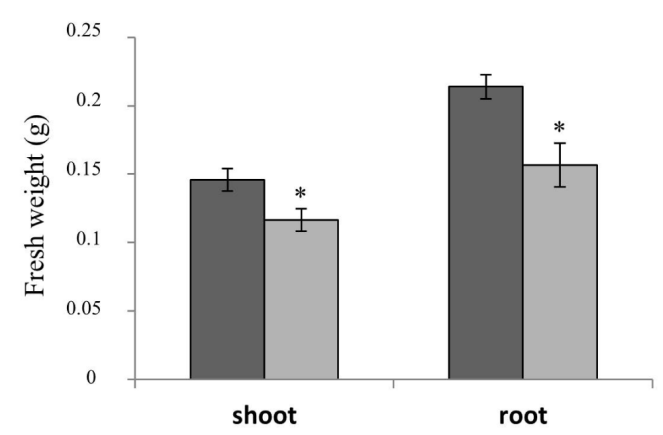

(a)

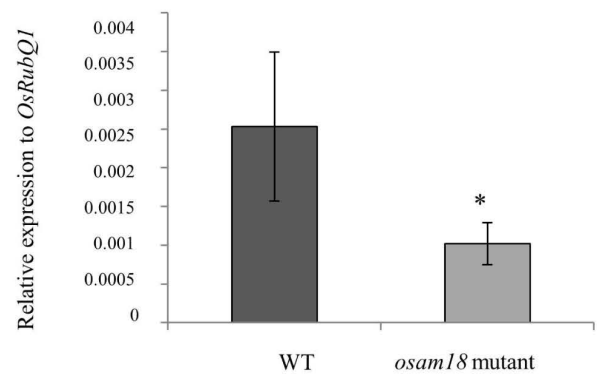

(c)

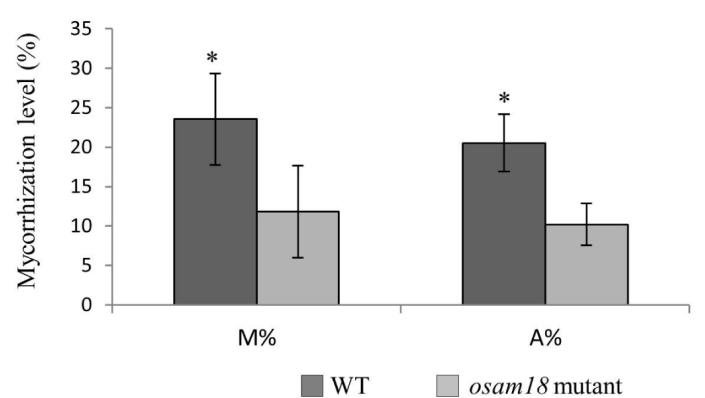

(b)
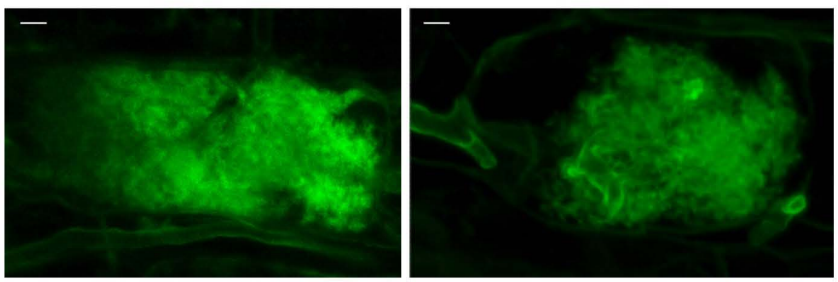

(d)

Figure 5. Phenotyping of osam 18 mutants colonized by the AM fungus Funelliformis mosseae. (a) Fresh weight of shoot and root of colonized osam 18 mutants and WT plants. Data are the average of at least four plants and \pm SE are represented by bars (Kruskal Wallis test). Asterisks indicate significant differences (Kruskal Wallis test, $\mathrm{P}<0.05$ ); (b) Degree of colonization expressed as mycorrhizal intensity (M\%) and arbuscule abundance (A\%) in the root system of both WT and osam 18 mutant plants. Data are the average of five biological replicates and $\pm \mathrm{SE}$ are represented by bars. Asterisks indicate significant differences (One-way Anova test, P < 0.05); (c) Quantitative expression of OSPT11 by qRT-PCR in mycorrhizal roots of WT and osam 18 mutant plants. Data are the average of at least three biological replicates and the bars represent $\pm \mathrm{SE}$. Asterisk indicates significant differences, with a $\mathrm{P}$ value $<0.05$; (d) Cortical cells from WT and osam 18 mutant plants containing arbuscules: green fluorescence is due to wheat germ agglutinin-fluorescein isothiocyanate. Scale bars: $10 \mu \mathrm{m}$.

The reason why the GRAS knock-out leads to a less successful symbiosis in the osam 18 mutant remains elusive. On one hand the fungal growth is partially inhibited leading to a decreased presence of both hyphae and arbuscules; on the other hand the mutation has an impact on AM functionality not only at the level of cortical cells (decreased transcripts of OSPT11), but also at systemic level (decreased size and weight of shoots and roots from mycorrhizal mutant plants). Since the mutation in itself does not cause any clear change in the phenotype of the non-colonized plants, it seems that $O S A M 18$ may act as a novel positive regulator of AM symbiosis: it could interact with some of the metabolic pathways which control plant growth response to AM fungi, like hormonal pathways or nutrient flow regulation. Moreover, we suggested that OsAM18 could be a component of the GRAS-domain proteins complex which is involved in the elicitation of AM symbiosis.

\section{Acknowledgements}

The authors express their thanks to Dr. Giampiero Valè and Mr. Gabriele Orasen for the support provided for plant growth and grains collection at CRA-RIS of Vercelli; and to Dr Marco Giovannetti for the useful discussion. Research was funded by the RISINNOVA Project (Grant No. 2010-2369, AGER Foundation) and the GreenRice Project (ERANET-FACCE), as well as VF and VV fellowship, respectively.

\section{References}

[1] Redecker, D., Schüßler, A., Stockinger, H., Stürmer, S.L., Morton, J.B. and Walker, C. (2013) An Evidence-Based Consensus for the Classification of Arbuscular Mycorrhizal Fungi (Glomeromycota). Mycorrhiza, 23, 515-531. http://dx.doi.org/10.1007/s00572-013-0486-y 
[2] Bonfante, P. and Genre, A. (2010) Mechanisms Underlying Beneficial Plant-Fungus Interactions in Mycorrhizal Symbiosis. Nature Communications, 1, 48. http://dx.doi.org/10.1038/ncomms1046

[3] Govindarajulu, M., Pfeffer, P.E., Jin, H.R., Abubaker, J., Douds, D.D., Allen, J.W., Bücking, H., Lammers, P.J. and Shachar-Hil, Y. (2005) Nitrogen Transfer in the Arbuscular Mycorrhizal Symbiosis. Nature, 435, 819-823. http://dx.doi.org/10.1038/nature03610

[4] Javot, H., Penmetsa, R.V., Terzaghi, N., Cook, D.R. and Harrison, M.J. (2007) A Medicago truncatula Phosphate Transporter Indispensable for the Arbuscular Mycorrhizal Symbiosis. Proceedings of the National Academy of Sciences of the United States of America, 104, 1720-1725. http://dx.doi.org/10.1073/pnas.0608136104

[5] Giovannetti, M., Tolosano, M., Volpe, V., Kopriva, S. and Bonfante, P. (2014) Identification and Functional Characterization of a Sulfate Transporter Induced by both Sulfur Starvation and Mycorrhiza Formation in Lotus japonicus. New Phytologist, 204, 609-619. http://dx.doi.org/10.1111/nph.12949

[6] Pfeffer, P.E., Douds, D.D., Becard, G. and Shachar-Hill, Y. (1999) Carbon Uptake and the Metabolism and Transport of Lipids in an Arbuscular Mycorrhiza. Plant Physiology, 120, 587-598. http://dx.doi.org/10.1104/pp.120.2.587

[7] Gutjahr, C. and Parniske, M. (2013) Cell and Developmental Biology of Arbuscular Mycorrhiza Symbiosis. Annual Review of Cell and Developmental Biology, 29, 593-617. http://dx.doi.org/10.1146/annurev-cellbio-101512-122413

[8] Hohnjec, N., Vieweg, M.F., Pühler, A., Becker, A. and Küster, H. (2005) Overlaps in the Transcriptional Profiles of Medicago truncatula Roots Inoculated with Two Different Glomus Fungi Provide Insights into the Genetic Program Activated during Arbuscular Mycorrhiza. Plant Physiology, 137, 1283-1301. http://dx.doi.org/10.1104/pp.104.056572

[9] Liu, J., Maldonado-Mendoza, I., Lopez-Meyer, M., Cheung, F., Town, C.D. and Harrison, M.J. (2007) Arbuscular Mycorrhizal Symbiosis Is Accompanied By Local And Systemic Alterations in Gene Expression and an Increase in Disease Resistance in the Shoots. The Plant Journal, 50, 529-544. http://dx.doi.org/10.1111/j.1365-313X.2007.03069.x

[10] Guether, M., Balestrini, R., Hannah, M., He, J., Udvardi, M.K. and Bonfante, P. (2009) Genome-Wide Reprogramming Of Regulatory Networks, Transport, Cell Wall And Membrane Biogenesis During Arbuscular Mycorrhizal Symbiosis in Lotus japonicus. New Phytologist, 182, 200-212. http://dx.doi.org/10.1111/j.1469-8137.2008.02725.x

[11] Fiorilli, V., Catoni, M., Miozzi, L., Novero, M., Accotto, G.P. and Lanfranco, L. (2009) Global and Cell-Type Gene Expression Profiles in Tomato Plants Colonized by an Arbuscular Mycorrhizal Fungus. New Phytologist, 184, 975-987. http://dx.doi.org/10.1111/j.1469-8137.2009.03031.x

[12] Javot, H., Penmetsa, R.V., Breuillin, F., Bhattarai, K.K., Noar, R.D., Gomez, S.K., Zhang, Q., Cook, D.R. and Harrison, M.J. (2011) Medicago truncatula Mtpt4 Mutants Reveal a Role for Nitrogen in the Regulation of Arbuscule Degeneration in Arbuscular Mycorrhizal Symbiosis. The Plant Journal, 68, 954-965. http://dx.doi.org/10.1111/j.1365-313X.2011.04746.x

[13] Yang, S.Y., Grønlund, M., Jakobsen, I., Grotemeyer, M.S., Rentsch, D., Miyao, A., Hirochika, H., Kumar, C.S., Sundaresan, V., Salamin, N., Catausan, S., Mattes, N., Heuer, S. and Paszkowski, U. (2012) Nonredundant Regulation of Rice Arbuscular Mycorrhizal Symbiosis by Two Members of the Phosphate Transporter1 Gene Family. The Plant Cell, 24, 4236-4251. http://dx.doi.org/10.1105/tpc.112.104901

[14] Balestrini, R. and Bonfante, P. (2014) Cell Wall Remodeling in Mycorrhizal Symbiosis: A Way towards Biotrophism. Frontiers in Plant Science, 5, 237. http://dx.doi.org/10.3389/fpls.2014.00237

[15] Xue, L., Cui, H., Buer, B., Vijayakumar, V., Delaux, P.M., Junkermann, S. and Bucher, M. (2015) Network of GRAS Transcription Factors Involved in the Control of Arbuscule Development in Lotus japonicus. Plant Physiology, 167, 854-871. http://dx.doi.org/10.1104/pp.114.255430

[16] Hogekamp, C., Arndt, D., Pereira, P.A., Becker, J.D., Hohnjec, N. and Küster, H. (2011) Laser Microdissection Unravels Cell-Type-Specific Transcription in Arbuscular Mycorrhizal Roots, Including CAAT-Box Transcription Factor Gene Expression Correlating with Fungal Contact and Spread. Plant Physiology, 157, 2023-2043. http://dx.doi.org/10.1104/pp.111.186635

[17] Gaude, N., Bortfeld, S., Duensing, N., Lohse, M. and Krajinski, F. (2012) Arbuscule Containing and Non-Colonized Cortical Cells of Mycorrhizal Roots Undergo Extensive and Specific Reprogramming during Arbuscular Mycorrhizal Development. The Plant Journal, 69, 510-528. http://dx.doi.org/10.1111/j.1365-313X.2011.04810.x

[18] Gobbato, E., Marsh, J.F., Vernié, T., Wang, E., Maillet, F., Kim, J., Miller, J.B., Sun, J., Bano, S.A., Ratet, P., Mysore, K.S., Dénarié, J., Schultze, M. and Oldroyd, G.E. (2012) A GRAS-Type Transcription Factor with a Specific Function in Mycorrhizal Signaling. Current Biology, 22, 2236-2241. http://dx.doi.org/10.1016/j.cub.2012.09.044

[19] Devers, E.A., Teply, J., Reinert, A., Gaude, N. and Krajinski, F. (2013) An Endogenous Artificial Microrna System for Unraveling the Function of Root Endosymbioses Related Genes in Medicago truncatula. BMC Plant Biology, 13, 82. http://www.biomedcentral.com/1471-2229/13/82

[20] Volpe, V., Dell'Aglio, E., Giovannetti, M., Ruberti, C., Costa, A., Genre, A., Guether, M. and Bonfante, P. (2013) An AM-Induced, MYB-Family Gene of Lotus japonicus (LjMAMI) Affects Root Growth in an AM-Independent Manner. 
The Plant Journal, 73, 442-455. http://dx.doi.org/10.1111/tpj.12045

[21] Yokota, K., Soyano, T., Kouchi, H. and Hayashi, M. (2010) Function Of GRAS Proteins in Root Nodule Symbiosis Is Retained in Homologs of a Non-Legume, Rice. Plant and Cell Physiology, 51, 1436-1442. http://dx.doi.org/10.1093/pcp/pcq124

[22] Di Laurenzio, L., Wysocka-Diller, J., Malamy, J.E., Pysh, L., Helariutta, Y., Freshour, G., Hahn, M.G., Feldmann, K.A. and Benfey, P.N. (1996) The SCARECROW Gene Regulates an Asymmetric Cell Division that Is Essential for Generating the Radial Organization of the Arabidopsis Root. Cell, 86, 423-433. http://dx.doi.org/10.1016/S0092-8674(00)80115-4

[23] Peng, J., Carol, P., Richards, D.E., King, K.E., Cowling, R.J., Murphy, G.P. and Harberd, N.P. (1997) The Arabidopsis GAI Gene Defines a Signaling Pathway that Negatively Regulates Gibberellin Responses. Genes and Development, 11, 3194-3205. http://dx.doi.org/10.1101/gad.11.23.3194

[24] Pysh, L.D., Wysocka-Diller, J.W., Camilleri, C., Bouchez, D. and Benfey, P.N. (1999) The GRAS Gene Family in Arabidopsis: Sequence Characterization and Basic Expression Analysis of the SCARECROW-LIKE Genes. The Plant Journal, 18, 111-119. http://dx.doi.org/10.1046/j.1365-313X.1999.00431.x

[25] Bolle, C. (2004) The Role of GRAS Proteins in Plant Signal Transduction and Development. Planta, 218, 683-692. http://dx.doi.org/10.1007/s00425-004-1203-Z

[26] Kaló, P., Gleason, C., Edwards, A., Marsh, J., Mitra, R.M., Hirsch, S., Jakab, J., Sims, S., Long, S.R., Rogers, J., Kiss, G.B., Downie, J.A. and Oldroyd, G.E. (2005) Nodulation Signaling in Legumes Requires NSP2, a Member of the GRAS Family of Transcriptional Regulators. Science, 308, 1786-1789. http://dx.doi.org/10.1126/science.1110951

[27] Smit, P., Raedts, J., Portyanko, V., Debellé, F., Gough, C., Bisseling, T. and Geurts, R. (2005) NSP1 of the GRAS Protein Family Is Essential for Rhizobial Nod Factor-Induced Transcription. Science, 308, 1789-1791. http://dx.doi.org/10.1126/science.1111025

[28] Lauressergues, D., Delaux, P.M., Formey, D., Lelandais-Brière, C., Fort, S., Cottaz, S., Bécard, G., Niebel, A., Roux, C. and Combier, J.P. (2012) The Micro-RNA Mir171h Modulates Arbuscular Mycorrhizal Colonization of Medicago truncatula by Targeting NSP2. The Plant Journal, 72, 512-522. http://dx.doi.org/10.1111/j.1365-313X.2012.05099.X

[29] Delaux, P.M., Bécard, G. and Combier, J.P. (2013) NSP1 Is a Component of the Myc Signaling Pathway. The New Phytologist, 199, 59-65. http://dx.doi.org/10.1111/nph.12340

[30] Floss, D.S., Levy, J.G., Lévesque-Tremblay, V., Pumplin, N. and Harrison, M.J. (2013) DELLA Proteins Regulate Arbuscule Formation in Arbuscular Mycorrhizal Symbiosis. Proceeding of the National Academy of Sciences of the USA, 110, E5025-E5034. http://dx.doi.org/10.1073/pnas.1308973110

[31] Hirsch, S. and Oldroyd, G.E. (2009) GRAS-Domain Transcription Factors that Regulate Plant Development. Plant Signaling and Behavior, 4, 698-700. http://dx.doi.org/10.4161/psb.4.8.9176

[32] Liu ,W., Kohlen, W., Lillo, A., Op Den Camp, R., Ivanov, S., Hartog, M., Limpens, E., Jamil, M., Smaczniak, C., Kaufmann, K., Yang, W.C., Hooiveld, G.J.E.J., Charnikhova, T., Bouwmeester, H.J., Bisseling, T. and Geurts, R. (2011) Strigolactone Biosynthesis in Medicago truncatula and Rice Requires the Symbiotic GRAS-Type Transcription Factors NSP1 and NSP2. The Plant Cell, 23, 3853-3865. http://dx.doi.org/10.1105/tpc.111.089771

[33] Yu, N., Luo, D., Zhang, X., Liu, J.,Wang, W., Jin, Y., Dong, W., Liu, J., Liu, H., Yang, W., Zeng, L., Li, Q., He, Z., Oldroyd, G.E. and Wang, E. (2014) A DELLA Protein Complex Controls the Arbuscular Mycorrhizal Symbiosis in Plants. Cell Research, 24, 130-133. http://dx.doi.org/10.1038/cr.2013.167

[34] Güimil, S., Chang, H.S., Zhu, T., Sesma, A., Osbourn, A., Roux, C., Ioannidis, V., Oakeley, E.J., Docquier, M., Descombes, P., Briggs, S.P. and Paszkowski, U. (2005) Comparative Transcriptomics of Rice Reveals an Ancient Pattern of Response to Microbial Colonization. Proceeding of the National Academy of Sciences of the USA, 102, 8066-8070. http://dx.doi.org/10.1073/pnas.0502999102

[35] Gutjahr, C., Banba, M., Croset, V., An, K., Miyao, A., An, G., Hirochika, H., Imaizumi-Anraku, H. and Paszkowski, U. (2008) Arbuscular Mycorrhiza Specific Signaling in Rice Transcends the Common Symbiosis Signaling Pathway. The Plant Cell, 20, 2989-3005. http://dx.doi.org/10.1105/tpc.108.062414

[36] Crumpton-Taylor, M., Grandison, S., Png, K.M., Bushby, A.J. and Smith, A.M. (2012) Control of Starch Granule Numbers in Arabidopsis Chloroplasts. Plant Physiology, 158, 905-916. http://dx.doi.org/10.1104/pp.111.186957

[37] Hewitt, E.J. (1966) Sand and Water Culture Methods Used in the Study of Plant Nutrition. Commonwealth Agricultural Bureaux, Farnham.

[38] Bairoch, A., Bucher, P. and Hofmann, K. (1997) The PROSITE Database, Its Status in 1997. Nucleic Acids Research, 25, 217-221. http://dx.doi.org/10.1093/nar/25.1.217

[39] La Cour, T., Kiemer, L., Mølgaard, A., Gupta, R., Skriver, K. and Brunak, S. (2004) Analysis and Prediction of Leucine-Rich Nuclear Export Signals. Protein Engineering, Design and Selection, 17, 527-536. 
http://dx.doi.org/10.1093/protein/gzh062

[40] Kawahara, Y., De La Bastide, M., Hamilton, J.P., Kanamori, H., Mccombie, W.R., Ouyang, S., Schwartz, D.C., Tanaka, T., Wu, J., Zhou, S., Childs, K.L., Davidson, R.M., Lin, H., Quesada-Ocampo, L., Vaillancourt, B., Sakai, H., Lee, S.S., Kim, J., Numa, H., Itoh, T., Buell, C.R. and Matsumoto, T. (2013) Improvement of the Oryza sativa Nipponbare Reference Genome Using Next Generation Sequence and Optical Map Data. Rice, 6, 4. http://dx.doi.org/10.1186/1939-8433-6-4

[41] Larkin, M.A., Blackshields, G., Brown, N.P., Chenna, R., Mcgettigan, P.A., Mcwilliam, H., Valentin, F., Wallace, I.M., Wilm, A., Lopez, R., Thompson, J.D., Gibson, T.J. and Higgins, D.G. (2007) Clustal W and Clustal X Version 2.0. Bioinformatics, 23, 2947-2948. http://dx.doi.org/10.1093/bioinformatics/btm404

[42] Paradis, E., Claude, J. and Strimmer, K. (2004) APE: Analyses of Phylogenetics and Evolution in R Language. Bioinformatics, 20, 289-290. http://dx.doi.org/10.1093/bioinformatics/btg412

[43] Charif, D. and Lobry, J.R. (2007) Seqin R 1.0-2: A Contributed Package to the R Project for Statistical Computing Devoted to Biological Sequences Retrieval and Analysis. In: Elias, G., Ed., Biological and Medical Physics, Biomedical Engineering, Springer, Berlin, 207-232.

[44] Dray, S. and Dufour, A.B. (2007) The Ade4 Package: Implementing the Duality Diagram for Ecologists. Journal of Statistical Software, 22, 1-20.

[45] Vallino, M., Fiorilli, V. and Bonfante, P. (2014) Rice Flooding Negatively Impacts Root Branching and Arbuscular Mycorrhizal Colonization, but Not Fungal Viability. Plant Cell and Environment, 37, 557-572. http://dx.doi.org/10.1111/pce.12177

[46] Trouvelot, A., Kough, J.L. and Gianinazzi-Pearson, V. (1986) Mesure Du Taux De Mycorhization VA D’un Syste 'Me Radiculaire. In: Gianinazzi-Pearson, V. and Gianinazzi, S., Eds., Mycorrhizae: Physiology and Genetics, INRA-Press, Paris, 217-221.

[47] Ririe, K.M., Rasmussen, R.P. and Wittwer, C.T. (1997) Product Differentiation by Analysis of DNA Melting Curves during the Polymerase Chain Reaction. Analytical Biochemistry, 245, 154-160. http://dx.doi.org/10.1006/abio.1996.9916

[48] Pérez-Tienda, J., Testillano, P.S., Balestrini, R., Fiorilli, V., Azcón-Aguilar, C. and Ferrol, N. (2011) GintAMT2, a New Member of the Ammonium Transporter Family in the Arbuscular Mycorrhizal Fungus Glomus intraradices. Fungal Genetics and Biology, 48, 1044-1055. http://dx.doi.org/10.1016/j.fgb.2011.08.003

[49] Hammer, Ø., Harper, D.A.T. and Ryan, P.D. (2001) PAST: Paleontological Statistics Software Package for Education and Data Analysis. Palaeontol Electron, 4, 9.

[50] Maillet, F., Poinsot, V., André, O., Puech-Pagès, V., Haouy, A., Gueunier, M., Cromer, L., Giraudet, D., Formey, D., Niebel, A., Martinez, E.A., Driguez, H., Bécard, G. and Dénarié, J. (2011) Fungal Lipochitooligosaccharide Symbiotic Signals in Arbuscular Mycorrhiza. Nature, 469, 58-63. http://dx.doi.org/10.1038/nature09622

[51] Gutjahr, C., Casieri, L. and Paszkowski, U. (2009) Glomus Intraradices Induces Changes in Root System Architecture of Rice Independently of Common Symbiosis Signaling. New Phytologist, 182, 829-837. http://dx.doi.org/10.1111/j.1469-8137.2009.02839.x

[52] Genre, A., Ivanov, S., Fendrych, M., Faccio, A., Zársky, V., Bisseling, T. and Bonfante, P. (2012) Multiple Exocytotic Markers Accumulate at the Sites of Perifungal Membrane Biogenesis in Arbuscular Mycorrhizas. Plant Cell Physiology, 53, 244-255. http://dx.doi.org/10.1093/pcp/pcr170 